\title{
Pengaruh Aplikasi Vermikompos Berbahan Aditif Pestisida Nabati Terhadap Pertumbuhan, Hasil Dan Serapan Hara N, P Dan K Tanaman Brokoli (Brassica oleracea L.) Yang Terinfeksi Hama Plutella xylostella
}

\author{
Prayoga Gumilar Geri Winarno ${ }^{1^{*}}$, Anis Sholihah ${ }^{2}$ dan Nurhidayati ${ }^{2}$ \\ ${ }^{1}$ Mahasiswa S1 Agroteknologi, Fakultas Pertanian, Universitas Islam Malang \\ ${ }^{2}$ Dosen Agroteknologi, Fakultas Pertanian, Universitas Islam Malang \\ JI. MT. Haryono No. 193 Malang 65144, Jawa Timur, Indonesia \\ *Korespondensi : prayogawinarno@gmail.com
}

\begin{abstract}
Abstrak
Untuk mengurangi dampak negatif dari penggunaan pestisida kimia terhadap lingkungan dalam sistem budidaya konvensional, perlu adanya teknik pengendalian alternatif secara organik dengan menggunakan pupuk organik dan pestisida nabati. Penelitian ini dilakukan untuk menjelaskan pengaruh aplikasi vermikompos berbahan aditif pestisida nabati terhadap pertumbuhan, hasil dan serapan hara tanaman brokoli (Brassica oleracea L.) yang terinfeksi hama Plutella xylostella. Penelitian merupakan percobaan pot menggunakan rancangan acak kelompok (RAK) sederhana yang terdiri atas 14 perlakuan yaitu P0 (kontrol), P1 (pupuk dan pestisida kimia) P2 - P13 (menggunakan vermikompos berbahan aditif pestisida nabati dengan cara aplikasi yang berbeda). Variabel yang diamati adalah variabel tumbuh, hasil serapan $\mathrm{N}, \mathrm{P}$ dan $\mathrm{K}$ tanaman. Hasil penelitian menunjukkan perlakuan P4 dan P6 memberikan pertumbuhan tanaman terbaik, perlakuan P4, P6 dan P8 memberikan berat segar total biomassa tertinggi berturut-turut dengan nilai 257,85 gram, 257,31 gram dan 250,64 gram, perlakuan P7 memberikan berat kering total biomassa tertinggi dengan nilai 37,32 gram, perlakuan P6 memberikan diameter floret terbesar dengan nilai $8,76 \mathrm{~cm}$ dan perlakuan P9 memberikan hasil indeks panen tertinggi dengan nilai $26,96 \%$. Perlakuan P4 memberikan serapan hara $\mathrm{N}$ dan $\mathrm{P}$ tertinggi dengan nilai berturut-turut 1,24 dan 0,16 gram tan. ${ }^{-1}$. Serapan hara $\mathrm{K}$ tertinggi pada perlakuan $\mathrm{P} 8$ dengan nilai 1,36 gram tan.$^{-1}$. Hasil penelitian ini menyarankan bahwa untuk pengendalian hama ulat Plutella xylostella secara organik, perlu aplikasi vermikompos dengan bahan aditif daun mimba + daun pepaya dan daun mimba + daun paitan yang dibenamkan
\end{abstract}

Kata Kunci: Vermikompos, pestisida nabati, serapan hara, pertumbuhan dan hasil tanaman, brokoli (Brassica oleracea L.), hama (Plutella xylostella)

\begin{abstract}
To reduce the negative impact of the use of chemical pesticides on the environment in conventionally plant cultivation, it is necessary to have alternative control techniques organically by using organic fertilizers and organic pesticides.. This study was conducted to describe the effect of vermicompost application made from organic pesticide additives on the growth, yield and nutrient uptake of broccoli (Brassica oleracea L.) infected with Plutella xylostella. The study was a pot experiment using a randomized block design consisting of 14 treatments, P0 (control), P1 (chemical fertilizer and pesticide) P2 - P13 (using different additive vermicompost and application methods). The observed variables included growth, yield, and $\mathrm{N}, \mathrm{P}$, and $\mathrm{K}$ uptake. The collected data were analyzed using ANOVA and tukey test $(P<0,05)$ and correlation analysis to determine the effect of nutrient uptake on crop yields. The results showed that P4 and P6 treatments gave the highest growth. Treatments P4, P6 and P8 gave the highest total fresh biomass weight by of $257.85 \mathrm{~g}, 257.31 \mathrm{~g}$ and $250.64 \mathrm{~g}$
\end{abstract}


respectively, $\mathrm{P} 7$ treatment gave the highest total dry weight of biomass by $37.32 \mathrm{~g}, \mathrm{P} 6$ treatment gave the largest floret diameter by $8.76 \mathrm{~cm}$ and $\mathrm{P} 9$ treatment gave the highest harvest index by $26.96 \%$. P4 treatment plants gave the highest $\mathrm{N}$ and $\mathrm{P}$ nutrient uptake by 1.24 and $0.16 \mathrm{~g}_{\text {plants }}{ }^{-1}$, respectively. The highest $\mathrm{K}$ uptake value in P8 treatment by $1.36 \mathrm{~g} \mathrm{plant}^{-1}$. The research results suggested that the treatment of P4 (vermicompost with additives of neem+papaya leaves and incorporated) and P6 (vermicompost with additives of neem +Tithonia leaves ) to control Plutella xylostella.

Keywords : Vermicompost, biopesticides, nutriens uptake, plant growth and yield, broccoli (Brassica oleracea L.), pest (Plutella xylostella)

\section{Pendahuluan}

Brokoli (Brassica oleracea L.) merupakan komoditas sayur yang bernilai ekonomis tinggi. Permintaan brokoli meningkat seiring dengan perubahan pola hidup sehat dari masyarakat. Demikian juga di pasar internasional, setiap tahun selalu mengalami peningkatan 20-30\% (Budiastuti, Harjoko dan Shelti, 2009).

Budidaya tanaman brokoli dicirikan oleh aktivitas pengendalian HPT secara kimia. Residu bahan kimia tersebut melekat pada tanaman dan bunga brokoli. Untuk menghasilkan brokoli yang berkualitas dan memiliki kandungan gizi tinggi perlu teknis budidaya secara organik dengan menggunakan pupuk organik yang berkualitas tinggi.

Vermikompos adalah pupuk organik yang berkualitas tinggi dan dihasilkan dari perombakan bahan organik yang dilakukan cacing tanah. Vermikompos merupakan campuran kotoran cacing tanah (kascing) dengan sisa media atau pakan dalam budidaya cacing tanah. Oleh karena itu, vermikompos merupakan pupuk organik yang ramah lingkungan dan memiliki keunggulan tersendiri dibandingkan dengan kompos lain. Vermikompos memiliki $\mathrm{C} / \mathrm{N}$ rasio yang rendah, mampu Penambahan pupuk organik ke dalam tanah memberikan beberapa keuntungan bagi tanah dan tanaman. Selain menyediakan hara juga menambah kandungan bahan organik dalam tanah yang membantu meningkatkan jumlah dan aktifitas metabolik biologi tanah dan kegiatan jasad mikro dalam membantu proses dekomposisi dalam tanah, memberikan kondisi fisik yang baik di dalam tanah, sehingga perkembangan perakaran tanaman menjadi lebih baik (Abdurachman dan Suryana, 2005). Salah satu pupuk organik yang memiliki kualitas tinggi adalah vermikompos. Aplikasi vermikompos mampu meningkatkan pertumbuhan, hasil dan kualitas tanaman sai Pak-coi, brokoli dan Kubis (Nurhidayati et al., 2015; Nurhidayati et al., 2016; Nurhidayati, 2017). Vermikompos memiliki pengaruh langsung dan tidak langsung terhadap 
tanaman. Pengaruh langsung dari vermikompos adalah menyediakan hara makro dan mikro yang dibutuhkan oleh tanaman untuk pertumbuhannya, sehingga berdampak langsung pada hasil tanaman. Sedangkan pengaruh tidak langsung adalah vermikompos mampu menekan serangan hama dan penyakit tanaman (Lazcano dan Domínguez, 2011)

Hama ulat Plutella xylostella merupakan jenis hama yang menyerang golongan kubis-kubisan termasuk tanaman brokoli. Serangan hama ulat Plutella xylostella menyebabkan penurunan hasil panen baik dari segi kualitas maupun kunatitas. Serangan yang ditimbulkan bisa mencapai 90\% (Retno, 2006). Kerusakan ini menyebabkan gagal panen pada tanaman brokoli. Kondisi ini merugikan petani sehingga para petani menggunakan insektisida kimia untuk mengendalikan ulat Plutella xylostella. Untuk mengurangi dampak negatif dari penggunaan pestisida kimia terhadap lingkungan, perlu adanya teknik pengendalian alternatif secara organik dengan menggunakan pupuk organik dan pestisida nabati.

Pestisida nabati adalah bahan yang berasal dari alam, seperti tumbuhtumbuhan yang digunakan untuk mengendalikan organisme pengganggu tanaman. Aplikasi pestisida nabati merupakan salah satu solusi ramah lingkungan dalam rangka menekan dampak negatif akibat penggunaan pestisida kimia yang berlebihan (Novizan, 2002; Kardinan, 2001). Pestisida nabati tidak hanya mengandung satu jenis senyawa aktif. Oleh karena itu pestisda nabati cukup efektif dalam mengendalikan hama. Dalam bidang pertanian penggunaan pestisida nabati dianggap sebagai cara pengendalian hama yang ramah lingkungan (Kardinan, 2011). Penelitian ini bertujuan untuk menjelaskan pengaruh aplikasi vermikompos berbahan aditif pestisida nabati terhadap pertumbuhan, hasil serapan hara $\mathrm{N}, \mathrm{P}$ dan $\mathrm{K}$ tanaman brokoli yang terinfeksi hama Plutella xylostella.

\section{Bahan Dan Metode}

Penelitian ini merupakan percobaan dengan pot yang dilaksanakan di rumah kaca Fakultas Pertanian Universitas Islam Malang dengan ketinggian \pm 550 mdpl dengan suhu $22,7{ }^{\circ} \mathrm{C}-30{ }^{\circ} \mathrm{C}$. Waktu pelaksanaan bulan Desember 2017 sampai April 2018. Analisis dilakukan di Laboratorium Fakultas Pertanian Universitas Islam Malang dan Universitas Brawijaya Malang. Percobaan ini menggunakan rancangan acak kelompok (RAK) sederhana yang terdiri atas 14 
perlakuan terdiri dari : P0 (tanpa vermikompos + tanpa pengendalian HPT), P1 (perlakuan pupuk anorganik dan pestisida kimia), $\mathrm{P} 2-\mathrm{P}_{13}$ merupakan vermikompos dengan bahan aditif yang berbeda, $\mathrm{P}_{2}$ (daun mimba + daun sirsak dibenamkan), P3 (daun mimba + daun sirsak dibenamkan dan disemprotkan), P4 (daun mimba + daun pepaya dibenamkan), P5 (daun mimba + daun pepaya dibenamkan dan disemprotkan), P6 (daun mimba + daun paitan dibenamkan), P7 (daun mimba + daun paitan dibenamkan dan disemprotkan), P8 (daun pepaya + daun paitan dibenamkan), P9 (daun pepaya + daun paitan dibenamkan dan disemprotkan), P10 (daun sirsak + daun paitan dibenamkan), P11 (daun sirsak + daun paitan dibenamkan dan disemprotkan), P12 (daun sirsak + daun pepaya dibenamkan), P13 (daun sirsak + daun pepaya dibenamkan dan disemprotkan) dosis vermikompos untuk dibenamkan sebesar 200 gram per $10 \mathrm{~kg}$ tanah sedangkan perlakuan lainnya 100 gram dibenamkan dan 100 gram disemprotkan sebagai pupuk organik cair.

Tanah yang digunakan dalam penelitian berjenis inceptisol dengan kadar $\mathrm{N} \mathrm{0,18 \%} \mathrm{;} \mathrm{C-Organik} \mathrm{1,69;} \mathrm{pH}$ 5,68 ; BO 2,20 \% dan $\mathrm{C} / \mathrm{N}$ ratio 9,35. Media tanam yang digunakan merupakan campuran tanah dan kotoran sapi dengan perbandingan 4:1. Aplikasi vermikompos dilakukan 1 minggu sebelum tanam untuk yang dibenamkan ke dalam tanah. Bibit brokoli ditanam setelah 21 hari persemaian dan berdaun 4 helai. Selanjutnya dilakukan Introduksi hama ulat Plutella xylostella setelah tanaman berumur $14 \mathrm{HST}$.

Umur Plutella xylostella yang diintroduksikan pada instar 2-3 atau ketika berumur 7 hari setelah menetas. Karena pada fase ini Plutella xylostella tidak terlalu kecil dan sangat ganas menyerang tanaman. Satu tanaman diintroduksikan 3 ekor ulat Plutella xylostella yang terus berkembang dari instar 2 berubah menjadi imago sehingga berkembang biak pada daun tanaman brokoli.

Variabel pengamatan meliputi panjang tanaman dan jumlah daun sebagai variabel pertumbuhan. Variabel hasil meliputi berat segar total biomassa, berat kering total biomassa, berat hasil bernilai ekonomis, diameter floret dan indeks panen serta serapan hara N, P dan K. Data yang dikumpulkan dianalisis ragam (ANOVA) dan diuji lanjut BNJ $5 \%$ untuk mengetahui perbedaan antar perlakuan. Analisis korelasi untuk mengetahui pengaruh serapan hara terhadap hasil tanaman brokoli. 
Hasil Dan Pembahasan

\section{Pengaruh Pemberian Vermikompos Berbahan Aditif Pestisida Nabati Terhadap Pertumbuhan Tanaman Brokoli.}

Hasil analisis ragam (ANOVA) menunjukkan bahwa pemberian vermikompos berbahan aditif campuran pestisida nabati dan cara aplikasinya berpengaruh nyata terhadap panjang tanaman.

Tabel 1. Jumlah Daun Dan Panjang Tanaman Brokoli Pada Perlakuan Aplikasi Vermikompos Berbahan Aditif Pestisida Nabati Pada Umur 35 Dan 49 HST

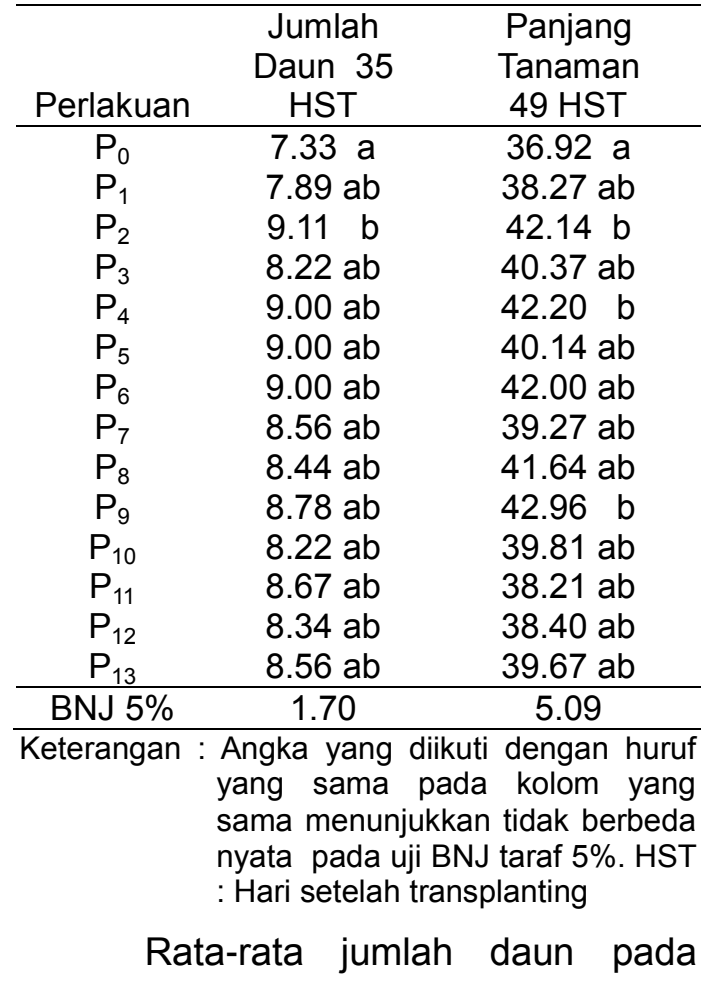

umur 35 HST perlakuan $\mathrm{P}_{2}$ memberikan jumlah daun terbanyak sebesar 9,11 helai tetapi tidak berbeda nyata dengan semua perlakuan kecuali PO. Pengamatan ke 49 HST perlakuan yang memberikan panjang tanaman tertinggi adalah $\mathrm{P}_{2}, \mathrm{P}_{4}$, dan $\mathrm{P}_{9}$. (Tabel 1). Penambahan pupuk organik ke dalam tanah memberikan beberapa keuntungan bagi tanah dan tanaman. Selain menyediakan hara juga menambah kandungan bahan organik dalam tanah yang membantu meningkatnya jumlah aktifitas metabolik biologi tanah dan kegiatan jasad mikro dalam membantu proses dekomposisi dalam tanah.

Selain itu bahan organik dapat memberikan kondisi fisik yang baik didalam tanah, sehingga perkembangan perakaran tanaman menjadi lebih baik (Nurhidayati, 2017; Havlin et al., 2005).

Tanaman brokoli yang tidak diberi pupuk vermikompos mengalami hambatan dalam pembentukan daun. Hal ini disebabkan tidak terpenuhinya kebutuhan unsur hara $\mathrm{N}$ yang berperan dalam pertumbuhan vegetatif tanaman. Pada fase vegetatif tanaman sangat memerlukan unsur nitrogen dan fosfor. Kedua unsur ini sangat berpengaruh dalam pembentukan sel dan komponen utama penyusun senyawa organik dalam tanaman seperti asam amino, asam nukleat, klorofil, ADP dan ATP (Herry dkk., 2013). Menurut lakitan (2001) N merupakan bahan dasar untuk membentuk asam amino dan protein yang digunakan tanaman untuk proses metabolisme. Jumlah $\mathrm{N}$ yang 
cukup akan memperlancar tanaman dalam metabolisme sehingga pertumbuhan organ seperti batang, daun dan akar menjadi lebih baik. Akar menyerap unsur hara yang diperlukan tanaman dalam bentuk vegetatif sehingga batang tanaman tumbuh tinggi dan mempengaruhi jumlah daun. Selain kandungan $\mathrm{N}$ yang cukup tinggi, vermikompos ini mengandung kalium yang tinggi karena menggunakan media dari sabut kelapa. Kalium dapat meningkatkan ketahanan tanaman dari kekeringan, hama dan penyakit (Lakitan, 2001).

\section{Pengaruh Pemberian Vermikompos Berbahan Aditif Pestisida Nabati Terhadap Hasil Tanaman Brokoli.}

Hasil analisis ragam (ANOVA) menunjukkan berbahan aditif campuran pestisida nabati dan cara aplikasinya berpengaruh nyata terhadap parameter hasil tanaman brokoli. Hasil uji BNJ $5 \%$ (Tabel 2) menunjukkan bahwa nilai rata-rata berat segar total biomassa tertinggi berturut-turut sebesar 257,85 gram, 257,31 gram dan 250,64 gram ditemukan pada perlakuan $\mathrm{P}_{4}, \mathrm{P}_{6}$, dan $\mathrm{P}_{8}$ tetapi tidak berbeda nyata dengan perlakuan $\mathrm{P}_{2}, \mathrm{P}_{5}, \mathrm{P}_{7}, \mathrm{P}_{9}, \mathrm{P}_{10}$ dan $\mathrm{P}_{13}$. Rata-rata berat kering total biomassa tertinggi terdapat perlakuan $\mathrm{P}_{7}$ yaitu sebesar 37,32 gram tetapi tidak berbeda nyata dengan semua perlakuan kecuali $P_{1}$ dan $P_{0}$ dengan hasil terendah pada perlakuan $\mathrm{P}_{0}$. Pada variabel berat bernilai ekonomis perlakuan $\mathrm{P}_{9}$ memberikan berat hasil bernilai ekonomis tertinggi sebesar 104,36 gram tetapi tidak berbeda nyata dengan perlakuan perlakuan vermikompos lainnya keculali perlakuan $P_{0}$.

Pada parameter diameter floret perlakuan $\mathrm{P}_{10}$ memiliki rata-rata diameter floret terbesar, tetapi tidak berbeda nyata dengan perlakuan $P_{1}$, $P_{2}, P_{6}, P_{7}, P_{8}, P_{9}$ dan $P_{12}$. Sedangkan pada variabel indeks panen brokoli, perlakuan $\mathrm{P}_{9}$ memiliki rata-rata indeks panen terbesar, tetapi tidak berbeda nyata dengan semua perlakuan kecuali $P_{0}$ dan $P_{12}$ dengan rata rata indek panen terendah pada perlakuan $\mathrm{P}_{12}$.

Pemberian vermikompos selain meningkatkan kesuburan tanah baik secara kimia, fisik dan biologi sehingga tanah mampu menopang pertumbuhan tanaman dengan baik. Vermikompos mengandung nutrisi yang dibutuhkan oleh tanaman guna mempercepat pertumbuhan dan meningkatkan biomassa tanaman.

Aplikasi vermikompos juga meningkatkan ketahanan tanaman terhadap serangan hama (Mashur, 2001; Lazcano dan Dominguez, 2011). Kondisi ini ditunjukkan oleh masih berlangsungnya pertumbuhan tanaman 
Tabel 2. Rata-Rata Hasil Tanaman Brokoli Pada Perlakuan Aplikasi Vermikompos Berbahan Aditif Pestisida Nabati

\begin{tabular}{|c|c|c|c|c|c|c|c|c|c|c|}
\hline \multirow{3}{*}{$\begin{array}{c}\text { Perlakuan } \\
\mathrm{P}_{0}\end{array}$} & \multicolumn{10}{|c|}{ Rata-rata hasil panen } \\
\hline & \multicolumn{2}{|c|}{$\begin{array}{l}\text { Berat segar } \\
\text { total biomassa } \\
\text { (g) }\end{array}$} & \multicolumn{2}{|c|}{$\begin{array}{l}\text { Berat kering } \\
\text { total biomassa } \\
\text { (g) }\end{array}$} & \multicolumn{2}{|c|}{$\begin{array}{c}\text { Berat hasil } \\
\text { bernilai ekonomis } \\
(\mathrm{g})\end{array}$} & \multicolumn{2}{|c|}{$\begin{array}{l}\text { Diameter } \\
\text { floret }(\mathrm{cm})\end{array}$} & \multicolumn{2}{|c|}{$\begin{array}{c}\text { Indeks Panen } \\
(\%)\end{array}$} \\
\hline & 150.31 & a & 19.78 & $a$ & 39.73 & $a$ & 5.69 & a & 26.07 & a \\
\hline $\mathrm{P}_{1}$ & 175.86 & $a b$ & 20.16 & $a$ & 55.17 & $a b$ & 7.51 & abcd & 30.46 & $a b$ \\
\hline $\mathrm{P}_{2}$ & 235.63 & def & 35.11 & $a b$ & 92.86 & abcd & 8.65 & $\mathrm{~cd}$ & 39.13 & $a b$ \\
\hline $\mathrm{P}_{3}$ & 198.50 & abcde & 26.33 & $a b$ & 79.80 & abcd & 6.42 & $a b c$ & 40.43 & $a b$ \\
\hline $\mathrm{P}_{4}$ & 257.85 & $f$ & 34.62 & $a b$ & 82.94 & bcd & 6.77 & abcd & 32.36 & $a b$ \\
\hline $\mathrm{P}_{5}$ & 229.99 & cdef & 33.82 & $a b$ & 97.39 & bcd & 6.07 & $a b$ & 42.11 & $a b$ \\
\hline $\mathrm{P}_{6}$ & 257.31 & $f$ & 37.03 & $a b$ & 101.00 & $\mathrm{~cd}$ & 8.76 & $d$ & 39.14 & $a b$ \\
\hline $\mathrm{P}_{7}$ & 248.63 & ef & 37.32 & $b$ & 76.08 & bcd & 8.29 & bcd & 30.70 & $a b$ \\
\hline $\mathrm{P}_{8}$ & 250.64 & $f$ & 35.48 & $a b$ & 102.93 & $\mathrm{~cd}$ & 8.41 & $\mathrm{~cd}$ & 40.95 & $a b$ \\
\hline $\mathrm{P}_{9}$ & 218.06 & bcdef & 31.17 & $a b$ & 104.36 & $d$ & 8.48 & $\mathrm{~cd}$ & 46.96 & $b$ \\
\hline$P_{10}$ & 246.01 & ef & 34.38 & $a b$ & 92.75 & $a b c$ & 9.01 & $d$ & 38.00 & $a b$ \\
\hline$P_{11}$ & 186.25 & abcd & 29.14 & $a b$ & 66.82 & abcd & 6.42 & $a b c$ & 35.94 & $a b$ \\
\hline$P_{12}$ & 181.90 & $a b c$ & 26.04 & $a b$ & 46.99 & abcd & 7.53 & abcd & 25.80 & $a$ \\
\hline$P_{13}$ & 206.75 & bcdef & 30.24 & $a b$ & 66.16 & abcd & 6.39 & $a b c$ & 31.95 & $a b$ \\
\hline BNJ 5\% & 51 & & 16.5 & & 48.7 & & 2.2 & & 18.04 & \\
\hline
\end{tabular}

\section{Pengaruh Pemberian Vermikompos Berbahan Aditif Pestisida Nabati Terhadap Serapan Hara $N, P$ dan $K$ Tanaman Brokoli}

Hasil analisis ragam (Anova) pemberian vermikompos berbahan aditif pestisida nabati memberikan pengaruh yang nyata terhadap serapan hara tanaman brokoli. Hasil analisis uji BNJ 5\% pada serapan hara N, P dan $\mathrm{K}$ (Tabel 3).

Tabel 3 menunjukkan bahwa perlakuan $\mathrm{P}_{4}$ (daun mimba + daun pepaya dibenamkan dalam tanah 200 gram polibag ${ }^{-1}$ ) memberikan serapan $\mathrm{N}$ tertinggi. Perlakuan $\mathrm{P}_{2}$ (daun mimba + daun sirsak dibenamkan dalam tanah dengan dosis 200 gram polybag $\left.^{-1}\right), \mathrm{P}_{4}$ (daun mimba + daun pepaya dibenamkan dalam tanah dengan dosis 200 gram polybag $^{-1}$ ), $\mathrm{P}_{5}$ (daun mimba + daun pepaya dibenamkan dalam tanah 100 gram dan disemprotkan 100 gram polybag $\left.{ }^{-1}\right), \quad\left(P_{6}\right.$ (daun mimba + daun paitan dibenamkan dalam tanah dengan dosis 200 gram polybag $^{-1}$ ) dan $\mathrm{P}_{8}$ (daun pepaya + daun paitan dibenamkan dalam tanah dengan dosis 200 gram polybag-1) memberikan serapan $\mathrm{P}$ yang tinggi. 
Tabel 3. Rata-Rata Serapan Hara N, P Dan K Tanaman Brokoli Pada Perlakuan Aplikasi Vermikompos Berbahan Aditif Pestisida Nabati

\begin{tabular}{|c|c|c|c|c|c|c|}
\hline \multirow{2}{*}{ Perlakuan } & \multicolumn{6}{|c|}{ Rata-rata serapan hara (gram/tanaman) } \\
\hline & $\mathrm{N}$ & & $\mathrm{P}$ & & $\mathrm{K}$ & \\
\hline $\mathrm{P}_{0}$ & 0,39 & $a$ & 0,06 & $a$ & 0,61 & $a$ \\
\hline $\mathrm{P}_{1}$ & 0,42 & $a b$ & 0,09 & a & 0,66 & $a b$ \\
\hline $\mathrm{P}_{2}$ & 0,95 & abcd & 0,16 & $b$ & 1,19 & $\mathrm{~cd}$ \\
\hline $\mathrm{P}_{3}$ & 0,86 & abcd & 0,11 & $a b$ & 0,85 & abcd \\
\hline $\mathrm{P}_{4}$ & 1,24 & $d$ & 0,16 & $\mathrm{~b}$ & 1,13 & abcd \\
\hline$P_{5}$ & 1,11 & $\mathrm{~cd}$ & 0,14 & b & 1,23 & $\mathrm{~cd}$ \\
\hline$P_{6}$ & 1,15 & $\mathrm{~cd}$ & 0,16 & $b$ & 1,15 & bcd \\
\hline $\mathrm{P}_{7}$ & 0,84 & abcd & 0,13 & $a b$ & 1,17 & bcd \\
\hline $\mathrm{P}_{8}$ & 1,06 & $\mathrm{~cd}$ & 0,16 & $b$ & 1,36 & $d$ \\
\hline $\mathrm{P}_{9}$ & 0,98 & abcd & 0,13 & $a b$ & 1,09 & abcd \\
\hline$P_{10}$ & 1,02 & bcd & 0,13 & $a b$ & 0,78 & $a b c$ \\
\hline$P_{11}$ & 0,81 & abcd & 0,13 & $a b$ & 0,99 & abcd \\
\hline$P_{12}$ & 0,55 & $a b c$ & 0,11 & $a b$ & 0,79 & $a b c$ \\
\hline $\mathrm{P}_{13}$ & 0,68 & abcd & 0,11 & $a b$ & 0,87 & abcd \\
\hline
\end{tabular}
$\begin{array}{cccc}\text { KNJ } 5 \% & 0,60 & 0,07 & 0,52 \\ \text { Keterangan : Angka yang diikuti dengan huruf yang sama pada kolom yang sama tidak } \\ \text { berbeda nyata pada uji BNJ taraf } 5 \% .\end{array}$

Sedangkan serapan $\mathrm{K}$ tertinggi pada perlakuan $\mathrm{P}_{2}$ (daun mimba + daun sirsak dibenamkan dalam tanah dengan dosis 200 gram polybag $\left.^{-1}\right), \mathrm{P}_{5}$ (daun mimba + daun pepaya dibenamkan dalam tanah 100 gram dan disemprotkan 100 gram polybag $^{-1}$ ) dan $\mathrm{P}_{8}$ (daun pepaya + daun paitan dibenamkan dalam tanah 200 gram polibag $^{-1}$ ).

\section{Vermikompos mampu} meningkatkan ketersediaan $\mathrm{N}, \mathrm{P}$ dan $\mathrm{K}$ dalam tanah serta meningkatkan populasi mikroba dalam tanah. Bila ketersediaan hara dalam tanah meningkat, maka serapan hara tanaman juga akan meningkat. Serapan hara ditentukan oleh konsentrasi hara dalam tanah (Nurhidayati, 2017).

Unsur $\mathrm{N}$ berfungsi untuk meningkatkan pertumbuhan vegetatif tanaman, meningkatkan kandungan klorofil, meningkatkan mikroorganisme tanah, mensintesa asam amino dan protein dalam tanah (Patti dkk., 2013). Fungsi unsur phospor sebagai salah satu unsur penyusun protein, dibutuhkan guna membentuk bunga, buah dan biji, merangsang pertumbuhan akar menjadi lebih panjang sehingga tanaman menjadi lebih kuat dan tahan terhadap kekeringan (Khoirudin dkk., 2016). Kalium digunakan tanaman dalam fungsi fisiologis yang berperan dalam metabolisme karbohidrat, aditifitas 
enzim, regulasi osmotik, efisiensi penggunaan air, serapan unsur $\mathrm{N}$, sintesis protein dan translokasi asimilat (Gunadi, 2009). Vermikompos mengandung unsur hara yang tinggi, tidak hanya menyediakan dalam jangka pendek tapi juga dalam jangka panjang karena adanya efek residu dari vermikompos (Nurhidayati et al., 2018).

\section{Pengaruh Serapan Hara $N, P$ dan $K$ terhadap Hasil Tanaman Brokoli}

Hasil analisis korelasi untuk mengetahui pengaruh serapan hara $\mathrm{N}$, $\mathrm{P}$ dan $\mathrm{K}$ terhadap variabel hasil tanaman brokoli disajikan pada Tabel 4 .

Tabel 4. Nilai Koefisien Korelasi antara Serapan Hara dengan Variabel Hasil Tanaman Brokoli

\begin{tabular}{llcc}
\hline \multirow{1}{*}{ Variabel } & \multicolumn{3}{c}{$\begin{array}{c}\text { Serapan Hara } \\
\text { (gram/tanaman) }\end{array}$} \\
\cline { 2 - 4 } & $\mathrm{N}$ & $\mathrm{P}$ & $\mathrm{K}$ \\
\hline $\begin{array}{l}\text { Berat bernilai } \\
\text { ekonomis }\end{array}$ & $0,79^{*}$ & 0,44 & 0,28 \\
\hline $\begin{array}{l}\text { Berat segar total } \\
\text { biomassa }\end{array}$ & $0,63^{*}$ & 0,31 & 0,03 \\
\hline $\begin{array}{l}\text { Berat kering } \\
\text { total biomassa }\end{array}$ & $0,54^{*}$ & 0,21 & 0,06 \\
\hline
\end{tabular}

Serapan $\mathrm{N}$ memberikan pengaruh yang besar terhadap variabel produksi (Tabel 5) dengan nilai $r=0,79$ pada berat bernilai ekonomis, $r=0,63$ pada berat segar total biomassa dan $r=0,54$ pada berat kering total biomassa. Nilai $r$ positif menunjukkan bahwa semakin tinggi serapan hara maka semakin tinggi hasil yang diperoleh.
Kandungan mikroba dalam vermikompos juga berperan dalam memperbaiki struktur dan tekstur tanah yang dapat meningkatkan daya serapan hara oleh akar ke dalam tanah (Zabati et al., 2013).

Pemilihan perlakuan $\mathrm{P}_{4}$ dan $\mathrm{P}_{6}$ sebagai perlakuan terbaik selain didasari dari segi hasil panen yang cukup tinggi juga dilihat dari segi bahan dasar pestisida nabati yang berupa daun mimba, daun pepaya dan daun paitan yang cukup mudah didapatkan. Hasil panen tanaman brokoli pada penelitian ini lebih kecil daripada hasil panen brokoli pada umumnya. Hal tersebut disebabkan karena beberapa faktor yang mempengaruh. Salah satu faktor yang mempengaruhi produksi tanaman brokoli adalah suhu, diperlukan suhu dibawah dari $23^{\circ} \mathrm{C}$ untuk merangsang terbentuknya floret (Fanham dan Bjorkman, 2011). Hal tersebut menyebabkan fase vegetatif terus berlanjut sehingga pada saat pembungaan menjadi kurang optimal. Selain itu penurunan pembungaan disebabkan oleh banyaknya cabang yang terbentuk sehingga ukuran brokoli menjadi kecil (Jaya, 2009).

Hasil tanaman brokoli bergantung pada luas daun tanaman. Daun tanaman brokoli yang terserang hama Plutella xylostella menjadi berlubang dan rusak, hal tersebut 
menyebabkan proses fotosintesis menjadi terhambat sehingga hasil panen menjadi lebih kecil dari tanaman brokoli pada umumnya. Luas daun yang semakin kecil menyebabkan laju asimilasi yang semakin kecil pula sehingga mengganggu proses pertumbuhan dan perkembangan tanaman (Jaya, 2009).

\section{Kesimpulan dan Saran}

Aplikasi vermikompos berbahan aditif pestisida nabati memberikan pengaruh nyata terhadap pertumbuhan, hasil dan serapan hara tanaman. Hasil tanaman dan serapan hara terbaik terdapat pada perlakuan $\mathrm{P}_{4}$ (daun mimba + daun pepaya dibenamkan dalam tanah dengan dosis 200 gram polybag ${ }^{-1}$ ) dan $\mathrm{P}_{6}$ (daun mimba + daun paitan dibenamkan dalam tanah dengan dosis 200 gram polybag ${ }^{-1}$ ) dengan rata-rata berat bernilai ekonomis sebesar 82,94 gram pada perlakuan $\mathrm{P}_{4}$ dan 101,00 gram pada perlakuan $\mathrm{P}_{6}$. Serapan hara $\mathrm{N}$ tanaman memberikan pengaruh terbesar terhadap hasil tanaman brokoli. Hasil penelitian ini menyarankan bahwa untuk mengendalikan hama Plutela xyllostela pada budidaya brokoli secara organik dapat menggunakan vermikompos dengan bahan aditif daun mimba, pepaya dan paitan.

\section{Daftar Pustaka}

Abdurachman A.,A. Suryana. 2005. Mengoptimalkan Sumber Daya Lahan Nasional untuk Pembangunan Pertanian dan Kesejahteraan Masyarakat. Satu Abad : Kiprah Lembaga Penelitian Tanah. 1905-2005. Pusat Penelitian dan Pengembangan Tanah dan Agroklimat. JI. Ir. H. Juanda 98 Bogor. $116 \mathrm{hlm}$.

Budiastuti, S., D. Harjoko Dan G. Shelti. 2009. Peningkatan potensi dan kualitas brokoli kopeng di Semarang Jawa Tengah melalui budidaya organik. Jurnal Agrivita. 31 (2) : 158-165.

Farnham, M. and T. Bjorkman. 2011. Breeding vegetebles asapted to high temperature: case studi with broccoli. Hort Sience. 46:1093-1097.

Gunadi, N. 2009. Kalium sulfat dan kalium klorida sebagai sumber pupuk kalium pada tanaman bawang merah. Jurnal Hortikultura. 19 (2) :174-185.

Havlin, J.L, J.D. Beaton, A.L. Tisdale and W.L. Nelson. 2005. Soil Fertility and Fertilizer. $7^{\text {th }}$ edion. Pearson Prentice Hall. Upper Saddle River New Jersey.

Herry D, Wardati dan Rosmimi. 2013. Pengaruh pupuk vermikompos pada tanah inceptisol terhadap pertumbuhan dan hasil sawi hijau (Brassica juncea. L). Jurnal Online Mahasiswa. 1 (1) 1-11.

Jaya, D. 2009. Pengaruh Pemangkasan Cabang Terhadap Hasil Tanaman Brokoli (Brassica oleraceae $L$ var. Italica) Di Dataran Rendah. Skripsi. Program Studi Hortikultura, Universitas Mataram. Mataram.

Kardinan, A. 2001. Pestisida Nabati Ramuan dan Aplikasi. Penebar Swadaya. Jakarta. 349 hal. 
Kardinan A. 2011. Penggunaan pestisida nabati sebagai kearifan lokal dalam pengendalian hama tanaman menuju sistem pertanian organik. Jurnal Pengembangan Inovasi Pertanian. 4 (4) 262278.

Kholidin, M., A. Rauf., H. N. Barus. 2016. Respon pertumbuhan dan hasil tanaman sawi (Brassica junce L.) terhadap kombinasi pupuk organik, anorganik dan mulsa di lembah palu. Universitas Tadulako. Palu. E-Jurnal Agrotekbis. 4 (1) : 1-7.

Lakitan, B. 2001. Dasar-Dasar Fisiologi Tumbuhan. PT. Raja Grafindo Persada. Jakarta. 205 hal.

Lazcano, C. and J. Dominguez. 2011. The use of vermicompost in sustainable agriculture : impact on plant growth and soil fertility. In : Soil Nutrients. Miransari, M. (Ed). ISBN : 978-1-61324-7853. Nova Sience Publishers, Inc. p 1-23.

Mashur. 2001. Vermikompos (Kompos Cacing Tanah). Instalasi Penelitian dan Pengkajian Teknologi Pertanian (IPPTP) Mataram. Mataram. http:/kascing.comarticlemashurv ermikompos.htm. Diakses tanggal 5 juli 2018.

Novizan, 2002. Membuat dan Memanfaatkan Pestisida Ramah Lingkungan. Agromedia Pustaka. Jakarta. 92 hal.

Nurhidayati. 2017. Kesuburan dan Kesehatan Tanah. Intimedia. Malang. $314 \mathrm{hlm}$.

Nurhidayati., M. Machfudz., I. Muwarni. 2018. Direct and residual effect of various vermicompost on soil nutrient and nutrient uptake dynamics and productivity of four mustard pak-coi (Brassica rapa L.) sequences in organic farming system. International Journal of Recycling of Organic
Waste in Agriculture. 7 (2) : 173-181.

Nuhidayati., M. Machfudz dan I. Muwarni. 2017. Pertumbuhan hasil dan kualitas tanaman brokoli sebagai respon terhadap aplikasitiga macam vermikompos dengan sistem penanaman secara organik. Prosiding Seminar Nasional. Optimalisasi Pemanfaatan Sumberdaya Lokal Menuju Kemandirian Pangan Nasional. ISBN : 978-602-61781-0-7. Hal. 175-190.

Patti. P.S, E. Kaya dan C. Silahooy. 2013. Analisis status nitrogen tanah dalam kaitannya dengan serapan $\mathrm{N}$ oleh tanaman padi sawah di Desa Waimital, Kecamatan Kairatu, Kabupaten Seram bagian barat. Jurnal Agrologia. 2 (1) 51-58.

Zabati, E., L. Wahyu. N.I. Mayta. 2013. Pengaruh dosis dan interval waktu pemberian pupuk organik cair nasa terhadap pertumbuhan dan produksi tanaman tomat (Solanum lycopersicum Lam.). Karya Ilmiah. Fakultas Matematika dan IImu Pengetahuan Alam. Universitas Riau. Riau. 